\title{
The Possibility of Vice-Presidents' Authority Arrangement in the 1945 Constitution through Constitutional Amendment
}

\author{
Fajar L. Suroso \\ Research Center and Assessment of the Constitutional Court of the Republic of Indonesia \\ Jl. Medan Merdeka Barat No. 6, Jakarta, 10110, Indonesia \\ Tel./Fax: +62-21-3520177E-mail:fajarlaksono@yahoo.com \\ Submitted: Dec 19, 2015; Reviewed: Jan 30, 2016; Accepted: Feb 12, 2016
}

\begin{abstract}
The debate over the vice-presidents' authority reappeared in the administration of President Jokowi after the "authority expansion of the Chief of Presidency Staff" and the case of "Rizal Ramli vs Jusuf Kalla". This article is intended to provide arguments for the idea of some parties to organize more explicit and detailed the authority of vice-president in the 1945 Constitution. The idea arises from the absence of further arrangement on the authority of vice-president in the 1945 Constitution. This article is systematized into 3 (three) sub-theme; 1) the arrangement of the vice-presidents'authority in the constitution for several countries; 2) The authority of the vice-president according to the 1945 Constitution, and 3) New resultant and the possibility of 1945 Constitution amendment. The result revealed a number of interesting things; 1) the constitutions of other countries do not specify the authority of the vice-president and put the vicepresident as a "spare tire" when the president is absent; 2) no new resultant about the position and authority of the vice-president so that theoretically is not reason enough to regulate in detail the authority of the vice-president through the 1945 Constitution amendment; 3) arrangement in detail in the authority of vice-president in the 1945 Constitution holds the potential to confuse the presidential system design as the 1945 Constitution. Therefore, the possibility of vice-presidents' authority arrangement in the 1945 Constitution through amendment is very small, both in terms of momentum and the substance of issues.
\end{abstract}

Keywords: Amendment; Authority; Constitutional Court; Vice-President

DOI: http://dx.doi.org/10.20956/halrev.v1n1.220

\section{INTRODUCTION}

This article gives argumentation the perspective of constitutional law regarding the idea of a number of parties to norm more explicit and detailed the authority of the vice-president in of the 1945 Constitution of the State of the Republic of Indonesia (hereinafter "the 1945 Constitution"). The norm is deemed necessary, because in the 1945 Constitution, the authority of the vice-president is still considered vague. Therefore, it is needed amendment of the 1945 Constitution to become clearer. In this case, the will to make re-amendment 
of the 1945 Constitution, among others, to norm the authority of the-vice president, reemerged again. The word "change" means conduct "formal amendment" as referred K.C. Whereas, ${ }^{1}$ not "informal amendment". According to Wheare, "formal amendment" is done according to the mechanism of amendment in the Constitution itself. Meanwhile, the "informal amendment" generally occurs through the practice of the Convention or the interpretation of a constitutional court. The argument on this point it is important and interesting put forward, in addition to seeing its possibility, as well as the encouragement of critical reasoning as described later.

Undeniably, re-emerge discourse concern the arrangement of vice-presidents' authority in the 1945 Constitution is related to 2 (two) events. First, when President Joko Widodo set a Presidential Regulation (Perpres) No. 26 of 2015 concerning the Office of the Presidential Staff. Presidential Regulation is rated as a form of authority expanding of the Chief of Presidential Staff. $^{2}$ In the presidential regulation is expressed that the role and coordinating functions of the ministry submitted to the Chief of Presidential Staff. Suspected, the expansion arises antagonize Vice-President

\footnotetext{
K.C. Wheare. (2005). Konstitusi-konstitusi Modern. Surabaya: Eureka, p. 121-145

2 In Article 3 letter (a) the Presidential Regulation No. 26 of 2015 is mentions one function of the Office of the Presidential Staff that is to do control in order to ensure the national priority program is conducted as vision and mission of the president. The presence of the Office of the Presidential Staff through the Presidential Regulation No.26 of 2015 is viewed so large than the arrangement in the Presidential Regulation No.190 of 2014 concerning Unit of Presidential Staff. The Chief of Presidential Staff is large incorporate to control the priority program, not only support the political communication and managing the presidential strategic issues as regulated in the Presidential Regulation No.190 of 2014.
}

Jusuf Kalla. ${ }^{3}$ Second, when the Ministry of Maritime Coordinator, Rizal Ramli, rated "bold" against Vice-President Jusuf Kalla, even to challenge him in a public debate. ${ }^{4}$ According to Jusuf Kalla, Rizal Ramli's behavior is excessive. ${ }^{5}$

After two events, a number of parties want to set the role and authority of the vice-president in the 1945 Constitution. It is expressed among others by the Chairman of the Regional Representatives Council (DPD) Irman Gusman, ${ }^{6}$ and the Chairman of the People Consultative Assembly (MPR), Zulkifli Hasan. According to Zulkifli, the amendment of the 1945 Constitution to confirm the position and authority of the vice president is necessary because the 1945 Constitution did not set authority

\footnotetext{
The Vice-President Jusuf Kalla assess, the adding of authority for the Chief of Presidential Staff arises excessive coordinating. At the end, this excessive coordinating is assessed tend to create ambiguity in the government coordination. According to Kalla, "possibly later the excessive coordinating if too more, there is again institution to coordinate the government, excessive later, if excessive is chaos". See, Kompas. "JK Mengaku Tidak Diajak Komunikasi Saat Jokowi Bentuk Perpres untuk Luhut”. March 4, 2015 edition.

4 Initially, incident emerge from the statement openly by Rizal Ramli concern 2 (two) things, (1) require the Ministry of Mineral Resource Economy and the National Energy Board to evaluate the governments' plan to realize the electrical project 35.000 MW until 2019. According to Rizal Ramli, the project is impossible, by giving the target is too high so it is difficult to achieve, and (2) require PT. Garuda Indonesia, Tbk to stop the buying of 30-unit Airbus A350 with a loan 44.5 US billions of China Aviation Bank, because the type of this airplane is only suitable to long distance flight between Jakarta to America and Jakarta to Europe.

5 Tempo News. "Ditantang Debat Terbuka, Wapres JK Akan Panggil Rizal Ramli”, available online at: http:// nasional.tempo.co/read/news/2015/08/19/078693268/ ditantang-debat-terbuka-wapres-jk-akan-panggil-rizalramli. Accessed on 15 May 2015.

$6 \quad$ Detik News. "Memperjelas Tugas Wapres, Ketua DPD: Perlu Amandemen UUD 1945 untuk Perkuat Peran Wapres". Available online at: http://news.detik.com/ berita/2999506/ketua-dpd-perlu-amandemen-uud1945-untuk-perkuat-peran-wapres. Accessed on $24 \mathrm{Au}-$ gust 2015.
} 
clearly to the vice-president. ${ }^{7}$ In Article 4 paragraph (2) of the Constitution 1945 stated, "In implementing his/her obligations, the President shall be assisted by one Vice President"'. Thereafter, the 1945 Constitution does not regulate further the authority of the vice-president. Therefore, the present practice, the vice-president is known as "auxiliary" or "substitute" of president. In fact, the vice-president was positioned as a "spare tire" and "bumper". ${ }^{8}$

As description above, the argument in this article is systematized according to a number of reasons as follows: First, what is needed the arrangement of vice-presidents' authority in the 1945 Constitution? If it is related to the view of K.C. Wheare, that the constitution of a country is resultante or agreement product of the situations of political, social, economic at given period, ${ }^{9}$ is there a new resultante to support the idea? In addition, through a comparison with the constitutions of other countries, whether usual the authority of the vice-president is explained in detail in the constitution? Second, if the authority of the vice-president is regulated in the 1945 Constitution, what its implication, whether further strengthen the authority of the president in a presidential system, or even undermine it?

Analisa Daily. "Wewenang Wapres Tak Jelas, MPR Kaji Amandemen UUD 1945". Available online at: http://news.analisadaily.com/read/wewenang-wapres-tak-jelas-mpr-kaji-amandemenuud-1945/163917/2015/08/24. Accessed on 25 August 2015.

8 Roy B.B. Janis. (2008). Wapres: Pendamping atau Pesaing? Peranan Wakil Presiden dalam Sistem Ketatanegaraan Republik Indonesia, Jakarta: Bhuana Ilmu Populer, p. 4

9 K.C Wheare. (1966). Modern Constitution, Second Edition. Oxford Paperbacks University Series: Oxford University Press, p. 33

\section{ANALYSIS AND DISCUSSION}

\section{The Arrangement of the Vice-Presidents'}

Authority in the Constitution for Several

\section{Countries}

To analyze the norm idea more explicit and detailed the authority of the vice-president in the 1945 Constitution, is relevant to see how the substance of the Constitution in several countries on the arrangement of vice presidents' authority. By knowing how many countries to norm the authority of vice-president, then it can be a comparison and benchmarks to accept or reject the arrangement idea of the vice-president in the 1945 Constitution. The following is reviewed regarding the arrangement of the vice-presidents' authority under the Constitution of United State, Colombia, and the Republic of Korea.

\section{United States}

In the US political system, which to present is considered as the best corner for the practice of presidential system in many countries, institutions of vice-president is established. In Article II Paragraph I the US Constitution stated that the executive power will be given to the US President. He will take his position within a period of four years, and together with the Vice-President, chosen for the same length of time.

Vice-presidents' function is defined in the US Constitution, but merely to do with the turn of the presidency and his role as Chairman of Senate. In addition, there are no details regarding the authority of the president. Based on Article I Paragraph 3 of the US Constitution, the Vice-President of the United States will be the Chairman of Senate, but do not have the Right to Vote, 
unless the number of votes divided equally. That is, his vote is only needed to avoid the rigidity of the situation due to the absence of a majority vote. In addition, according to Paragraph 1 of the US Constitution Amendment XXV (1967), declared in case the President excluded from his position or dies or resigns, the vice-president will become the president.

As the provision above, Roger Sherman noted, if not lead the Senate, the vicepresident is a position without a job. In other words, without the ceremonial duties, the vice-president does not have "another job". The role of the vice-president in the constitutional is very passive, just waiting for the constitution and presidential orders, the rest, he must be silent. ${ }^{10}$ That is, everything done the vice-president is come and sourced from the president. In the history of United States, only Henry Wallace, the only vicepresident is given great job by President Franklin D. Roosevelt, as Head of the Board of Economic Warfare. Other vice, practically does not have serious duties to do. ${ }^{11}$

Furthermore, the institution of the vice-president is added to the constitutional system to address the issue of succession, ${ }^{12}$ especially in terms of leadership succession if the president is absent. In exceptional circumstances, for example, when the president dies or a successful impeachment obviously will cause chaos. It is true that elections for

\footnotetext{
${ }^{10} \quad$ Arthur Schlesinger Jr., Is the Vice Presidency Necessary? http://www.theatlantic.com/magazine/archive/1974/05/ is-the-vice-presidency-necessary/305732/. Accessed on 11 November 2015 at 19.07 WIB

11 Ibid

12 "Why did the Founding Fathers create the Vice Presidency?". Available online at: http://www.thisnation. com/question $/ 039 . \mathrm{html}$. Accessed on 11 November 2015 at 18.05 .
}

a new president can take place immediately afterwards, however, generally it will take three or four months but the show must go on. So, if the position of the vice-president is absent, who becomes the President? ${ }^{13}$ One suggestion is appoint the Chairman of Parliament as the President for thirty days. At the same time, Congress chose President. However, because this suggestion has drawbacks, especially bearing in mind that one party has control of the legislative branch and other has control for executive, it obviously lead to instability. ${ }^{14}$ In this case, hard to say, the vice-president has only one serious thing to do, that is, waiting for the President to die. ${ }^{15}$ So, as stated by John N. Garner that the vice-president remains as "spare tire" in a government car.

His desire to enhance the role of VicePresident Theodore Roosevelt in 1896 when he became the vice-president. Theodore Roosevelt stated, "...would be very good if the Vice-President were given a seat in the cabinet." However, when the later was elected as a president, Roosevelt did not give the role of the Vice-President Charles W. Fairbanks, either in the cabinet or anywhere else. Along with it, the position of the vice-

\footnotetext{
Arthur Schlesinger Jr., Op.Cit.

14 Ibid

15 In fact, 9 (nine) the vice-president of United States occupy position after the president dies or absent. John Tyler replaces William Harrison died. Even so, Millard Fillmore became president after the death of President Zachary Taylor. Andrew Johnson rose to the presidency after the death of Abraham Lincoln. Chester A. Arthur appointed as president when James Garfield became a murder victim. As also Theodore Roosevelt, became president after President William McKinley was killed, although it was later elected in the next election. Calvin Coolidge replace President Warren Harding died. Franklin D. Roosevelt who died was replaced by Harry S. Truman. Post-killing John F. Kennedy, Lyndon B. Johnson was appointed as president. President Gerald Ford replaced Richard Nixon who resigned because of pressure after the Watergate scandal.
} 
president is a "training ground" for the future president. ${ }^{16}$

\section{Colombia}

In the Columbia's Constitution 1991 (as amended in 2005), concerning the vicepresident is set in Chapter III of Article 202-205. In Article 202 is essentially stated, the vice-president is chosen through election on the same day and in the same way with the President. More regulated, the vicepresident shall hold his position for the same period as the President. The Vice-President will replace the President in case of vacancy of the president, either temporarily or permanently. Determined also, "The President of the Republic will be able to entrust to the Vice President missions or special duties and to assign to him/her any responsibility of the Executive Branch." 17

Although set in a separate chapter, the setting indicates 2 (two) important things. First, the position of the vice-president of Colombia is closely linked to the succession of leadership, especially in the case of the president is unable to fulfill his duties, either temporary or permanent. Second, regarding the duties and responsibilities of the vicepresident is highly dependent on the trust

16 It proved, 5 (five) the Vice-President of United State successful as president. After 1789-1797 become the vice-president, John Adams was elected as President in 1796. Thomas Jefferson, the vice president during 1797-1801, finally won a presidential election contestation in 1800. Martin Van Buren, the vice president for $183-1837$, rose to the presidency in 1836. Similarly, George H.W Bush, the vice president in 1981-1989, to occupy the presidency after winning the elections in 1988. One again, Richard Nixon, the vice-president of Dwight D. Eisenhower during 1953-1961, was elected when candidating for president in 1968, Ibid.

17 See Colombia's Constitution of 1991 with Amendments through 2005. Available online at: https://www.constituteproject.org/constitution/Colombia_2005.pdf. Accessed on Thursday, 12 November 2015 at 09.30 WIB given by the president. That is, the president can give trust, and not. In other words, there are no specific rules in the Colombian Constitutional that govern duties and responsibilities of the vice-president.

President of Colombia, Juan Manuel Santos, announced that his government would consider whether the position of vice president in the government of Colombia is still needed. The position and role of the vice president needs to be reexamined in Colombia especially after the Vice-President Angelino Garzón is not optimal to do his position due to the health condition. In an interview with the Colombian newspaper El Tiempo, President Santos explained that point and have a successful president become president, it is better than having the office of the vice-president, as "cheaper" ${ }^{18}$ Although it must be acknowledged, the reason for eliminate the vice president appears to come from personal opinion Santos as implications of a close relationship Garzon with former President Alvaro Uribe, Santos' political rival. ${ }^{19}$

In Latin America, Colombia is not only country that expressing want to eliminate the vice-president. In Chile, the vice presidents' seat is eliminated under the constitution 1.833. Mexico has only seven vicepresidents before the position was eliminated during the Queretaro Congress of 1917. In Argentina, the vice president is still an active figure, but with the presence of irregular, because it is empty or absent in 1861-62,

\footnotetext{
18 Robert Valencia. (2012). "Are Vice Presidents Necessary?". Available online at: http://www.worldpolicy. org/blog/2012/09/06/are-vice-presidents-necessary. Accessed on 11 November 2015 at 18.17 WIB.

19 Ibid.
} 
1966-1973, and 1974-1983. Brazil eliminates the position of vice president in 1934 and restored in 1946. In Venezuela, Hugo Chavez under the "Fifth Republic," there is no single influential vice-president. Seven vice-presidents have comes and gone since Chavez came to power in 1999, each of which was replaced after one year of service with no explanation. ${ }^{20}$

\section{Republic of Korea}

As a country with presidential system, the Republic of Korea does not have a vicepresident. Whereas previously, since the temporary government and the period of 1948-1960, Korean constitution regulate the existence of the vice-president institution. ${ }^{21}$ Based on the Constitution of the Second Republic $^{22}$ set 16 June 1960, along with the strengthening of fundamental rights, press-freedom, the establishment of a new Constitutional Court, and the election commission, the vice-president institution is eliminated by restoring back the prime minister with full responsibility to the National Assembly. ${ }^{23}$

The elimination of vice-president institutions is based on the political facts at the time. The winning of President Syngman

20 Ibid.

21 Soong Hoom Kil and Chung-in Moon (ed.). (2001). Understanding Korean Politics: An Introduction. New York: State University of New York Press, p. 529

22 Korean constitutional order is divided into 3 (three) periods, namely (1) the first constitutional democracy period (1948-1972), (2) the authoritarian democracy period (1972-1987), and (3) the second constitutional democracy period (1987-present). The first constitutional democracy period is divided into 3 (three) periods, namely (i) the First Republic (1948-1960), (ii) the Second Republic (1960-1961), and the Third Republic (1963-1972).

23 James E. Hoare. (2015). Historical Dictionary of the Republic of Korea. Third Edition, Rowman \& Littlefield, Lanham, Maryland, p. 144
Rhee (Liberal Party) in the presidential election on 15 May 1955, was not followed by the winning of the vice-presidential candidate, Lee Ki-Bung. The winning it achieved by Chang Myun, candidate of the Democratic Party. ${ }^{24}$ The elimination is a continuation of the fact that the vice-president comes from the opposition is an ironic, given the constitutional provisions governing the vice president as an auxiliary or substitute the president in an emergency. ${ }^{25}$

Based on the Fifth Amendment as a result of national referendum in 1963, the president was given the authority to appoint the prime minister without the approval of the National Assembly. ${ }^{26}$ However, the provision was changed in the last amendment in 2005. In Article 86 the Constitution of Korea stated that the prime minister is appointed by the president with the approval of the National Assembly. In complete, "The Prime Minister shall be appointed by the President with the consent of the National Assembly". Further mentioned, the prime minister should help the president. The complete stated, "The Prime Minister shall assist the President and shall direct the Executive Ministries under order of the President."

Related to the condition in which the President is unable to perform his duties for any reason, the Constitution of Korea determines, the prime minister as substitute. However, not only the prime minister, members of the Council of State $^{27}$ which has

24 Juergen Kleiner (2001). Korea A Century of Change, Economic Ideas Leading to the 21st Century. Vol. 6, World Scientific Publishing Co. Pte. Ltd, pages. 111112

25 Soong Hoom Kil, Op.Cit, pages. 143-144

26 James E. Hoare, $O p$. Cit

27 Article 88 of the Constitution of Korea, "the composition of the state council shall comprise the President, 
priority by law also is able to act on it. For more detail, the arrangement in Article 71 states:

If the Office of the President is vacant or the President is unable to perform his duties for any reason, the Prime Minister or the members of the State Council in the order of priority as determined by Act, shall act for him.

According to the Constitution of Korea, the executive branch consists of the President, assisted by the prime minister and the Council of State. In Article 86 stated, "The Prime Minister shall assist the President and shall direct the Executive Ministries under order of the President". Meanwhile, in Article 87 stated, "The State Council shall deliberate on important policies that fall within the power of the Executive". From these provisions, the prime minister and the Council of State to work only on the basis and in the name of the Presidents' order.

The provisions above, the position of vice president in the Constitution of Korea can be concluded, (1) the presence of the vice-president is set as an auxiliary or substitute the president in an emergency; (2) the presence of the vice-president of the Constitutional provisions for political reasons, because the election was held separately, enabling the elected vice-president comes from the opposition parties that contradict to the president, (3) the role of the vice president is substituted by the prime minister or a member of the Council of State.

Based on the explanation of the three countries constitution above, it can be noted

\footnotetext{
the Prime Minister, and members who are not more than 30 people but no less than 15 people. The President is the Chairman of the State Council, while the Prime Minister as Deputy Chairman".
}

a few things. First, regarding the authority of the vice president did not set a clear or detailed. If it is set, as the case in the United States Constitution, only regulate the authorities of mere ceremonial. ${ }^{28}$ Second, the position of vice president is designed as "spare tire" for the presidency. The proof, in the three constitutions is simply set on the role of the vice president as a "successor" in the situation the president is unable, either temporarily or permanently. Even in the Republic of Korea, the position of vice-president is eliminated for ironic fact: the vice president as a "successor" actually the president comes from the opposition party. Third, the authority of the vice president is dependent on the president. The order comes from a single order, the president. If the president does not give orders, the vice president does not have the authority, either determine the policy and/or acting on behalf of the government.

\section{The Authority of the Vice-President as the 1945 Constitution}

In Article 4 paragraph (2) of the 1945 Constitution stated, "In implementing his/her obligations, the President shall be assisted by one Vice President". The problem, as has been stated, the 1945 Constitution does not regulate or assert more about it. To find out how the authority of the vice-president as the 1945 Constitution, it is important to give the interpretation of Article 4 (2) of

28 In the United States, there are at least three ceremonial of the vice-president duties, namely: (a) as Chairman of Senate presiding high rooms legislature no right to vote; (b) announced the winner of the presidential election in front of Regional Representative Council (DPD) and the House of Representative (DPR); (c) represent the president in the event of a state on the orders of the president. 
the 1945 Constitution. And also finding out how the position of the vice president to the president. Have many opinions and studies regarding the interpretation of the provision.

Regarding the duties and authority of the vice president, in the book titled "Pengisian Jabatan Presiden", Harun Al Rashid suggests 3 (three) duties of the Vice President under Article 4 (2) of the 1945Constitution, namely: (1) assist the president to perform his duties regularly; (2) performing the presidents' duties if the president is absent; and (3) substitute the president if the presidency is vacant. ${ }^{29}$

Bagir Manan, ${ }^{30}$ mentioned the vice president as presidents' auxiliary, therefore, the duty and authority of the vice president depends on his order or delegation of powers of the president. In the case of power-given, the Vice President acted on his own behalf (as a vice-president), whereas the delegation of powers, the Vice President acting on behalf of the President.

As for the position of the vice-president, Kuntana Magnar mentions two possibilities: (1) equal to the president, or (2) under the president. ${ }^{31}$ In the first possibility, between the president and the vice president there is no hierarchical relationship superior and subordinates. Cites Wirjono Prodjodikoros' view, which is seen only the priority-sharing in implementing the government power. In this case, the president is the first priority (the first man), while, the vice president as

29 Harun Al Rasyid. (1999). Pengisian Jabatan Presiden. Jakarta: Pustaka Utama Graffiti, p. 66

30 Bagir Manan, Macam-macam Peraturan Perundangundangan dan Keputusan Pemerintah RI Tahun $1945-$ 1949. (Paper), p, 16

31 Bagir Manan and Kuntana Magnar. (1997). Beberapa Masalah Hukum Tata Negara Indonesia, Bandung: Alumni, pages. 27-28 second priority (the second man). ${ }^{32}$

Furthermore, as the second man, when the president is absent temporarily or permanently, then the vice president immediately carries out the president's powers as specified in the 1945 Constitution. According to this logic, the vice president is not merely a presidential auxiliary whose duties and authorities are dependent on the president. In this case, the vice president is an element of leadership the implementation of staterun collegially by the president and the vice president. The act of president is an act of the vice-president as well. Instead, the act of the vice president is the act of the president as well. That is, the act of the vice president is an order acts, moreover, according to Article 4 paragraph (1) of the 1945 Constitution, the President is the Government.

Meanwhile, regarding the position of the vice president under the president, it is known by link to the Article 4 (2) and Article 5 the 1945 Constitution. Based on the provision, the President is only highest state government administrators. Consequently, all the responsibility is on the shoulders of the president. This indicates, the meaning of "assisted" in Article 4 paragraph (2) of the 1945 Constitution is a reflection of the position of the president is above the vicepresident. Consequently, the vice president cannot act alone. In its capacity as a "auxiliary", the duties and obligation of the vice president is absolutely dependent on the president. Musmuliadin, ${ }^{33}$ when assessing

\footnotetext{
$32 \quad$ Ibid, page. 27

33 Musmuliadin. (2013). "Tugas dan Kewenangan Wakil Presiden dalam Sistem Presidensiil Berdasarkan Undang-Undang Dasar Negara Republik Indonesia Tahun 1945", Jurnal Ilmiah, Fakultas Hukum Universitas Mataram, pages. 5-6
} 
the position of the vice president, emerging the term "auxiliary", "substitute" and "counterpart", and "represents" the president. According to Article 4 (2) of the 1945 Constitution, the vice president is not another is an auxiliary to the president in performing his obligations. So, the vice president acts to represent the pre-sident in the president are unable to perform his duties within the scope of the president's constitutional obligation.

In addition, when the president cannot fulfill his constitutional duty for some reason that can be justified by the law, then the Vice President can act as a substitute for the president. On another occasion, the vice president can also act as counterpart for the President in performing his duty. Citing Morissans' opinion, the vice president becomes the first man if the president is absent. The definition of "assisted" will remain valid as long as the president is still functioning. Meanwhile, the role of "auxiliary" is lost if the president remains incapacitated, because the vice president appeared as a substitute until the end of his position. ${ }^{34}$

More specifically, by conducting a review of the provisions of the Constitution 1945, particularly that regulate the implementation of state government, more specifically related to the presence of the vice president, as well as empirical experience, found at least 3 (three) the authority of the Vice President, as follow:

\section{"Vice" of President}

In this case, Vice-President is an official representing the president in performs the duties and obligations as well as the authority

$34 \quad$ Ibid of the president. Certainly, there must be first things that caused the president is absent, mainly temporary. For example, the vicepresident represents the president to visit the area or abroad, announce officially certain events, and others that are similar. In the capacity of representing the president, the vice president must get orders. Without the president order, the vice-president cannot represent the president. Order is mandate. Theoretically, as mandans, the president can withdraw anytime his mandate of the vice president as the mandatory.

\section{Auxiliary of President}

This authority is known by initially know the basic authority of the Presidents' authority as a basis of the vice president. One of the president's authorities is set under Article 4, paragraph (1) and (2) of the 1945 Constitution. If both are linked, then the vice president gave "assistance" to the President in the field of implementation of the governmental power. ${ }^{35}$ The assistance of the vice president to the president such assistance in implementing the legislation. This is in line with the oat/promise of president and vice president as set in Article 9 paragraph (1) the 1945 Constitution. Although it is not yet clear, too, whether the vice president can take the initiative to assist or wait for an order the president asked.

\section{Substitute of President}

As a substitute for the president, a vice president is no longer called the vice president, but as a president. After substituting the po-

\footnotetext{
35 Sri Soemantri. (1993). Tentang Lembaga-lembaga Negara Menurut UUD 1945. Bandung: Citra Aditya Bakti, page. 116
} 
sition of president is vacant, the vice president immediately separated from his position as the vice-president.

In addition to the third position above, in fact widely known that the vice president as a state organ or public official, independent authority to perform anyway. Indeed, there are no rules in the Constitution 1945 regarding this independent authority. But in practice, the vice president is often requested by individuals, groups or social organizations, such as a speaker, opened the event, cut the ribbon to inaugurate the building or particular location, and others that are similar. Thus, make a number of parties said the vice president performs independent authority, unless another desired by the President or legislation.

However, to speaking that the vice president has independent authority is needed prudence. According to the author, there are a number of notes on the issue. First, although it is suggested "independent", the formal authority of the vice president remained within the corridor of the authority, so that all the implementation must be known the president. Therefore, after exercise these authorities, should the duty of the vice president to immediately report to the president. Second, so-called this independent authority is generally ceremonial, not substantive. Third, the position of the vice president is not inherent to the right and independent authority to issue the decree on behalf of his position. ${ }^{36}$

36 The distortion of the vice presidents' authority ever happened in the history of Indonesia, at least 2 (two) times. First the Vice-President Mohammad Hatta set Edict X on 16 October 1945. In essence, the edict governing the submission of legislative power of Soekarno to the Komite Nasional Indonesia Pusat (KNIP). The act of Vice President Mohammad Hatta is intended to
The emergence of various classification of the vice presidents' authority shows a few things, such as (1) the presence of the vice president institutions are order of the 1945 Constitution, but the area and boundaries of authority is not regulated; (2) the 1945 Constitution did not explain how exactly the format of setting the working relationship between the president and the vice-president. From both, then it can be known the design of the 1945 Constitution system on the vice president. Since the beginning, the state founders held the position of vice-president to the passive position and prepared to fill the potential of president void, both temporally and permanently.

The construction of the vice president as a "spare tire" for the president is found in Article 8 (1) of the 1945 Constitution, "If the President passes away, resigns, is dismissed, or can not implement his/her obligations in his/her term of office, he/she shall be replaced by the Vice President until expiry of his/her term of office." By doing so, policy concerning the authority and the duty of the vice president, is the authority of president to decide. It is back on the principle: the president is the sole holder of the power

prevent the President from the trap of authoritarian rule since it holds all the authorities of state rule branches: executive, legislative, and judicial. Also, the edict as the first tension in the relationship between the President and Vice-President. Second. In 2005, the Vice-President Jusuf Kalla never signed the Decree of the Vice President on the Establishment of Tim Nasional Penanganan Bencana Aceh. The issuance of the decree, in the perspective of constitutional law is a mistake. It is true; often get special duties of vice president, including Vice President Jusuf Kalla who was then assigned by the President to lead the handling of post-disaster Aceh. However, that does not mean the vice president has the independent authority on the task, because after all, the authority issuing the decision solely in the hands of the president. That is, although given the special task, all decisions should the president decide. 
of government so that all the responsibility upon the president (concentration of power and responsibility upon the president). Therefore, in Chapter III the Power of State Government, the establisher of the 1945 Constitution is no one articles regulate the authority of the vice president. Based on the description, in general the positions of the vice president in the 1945 Constitution are constructed the same as the Constitution of the United States, Colombia, and the Republic of Korea: not set clear and in detail, his position as successor to the president, and the duties dependent on the president.

\section{New Resultante and the Possibility of}

\section{Amendment of the 1945 Constitution}

The construction of position and authority of the vice president in the 1945 Constitution is clearly in the development of practices deemed as "vague". Due to the vague, during this the president and the vice president are sharing role and authority through the conventions. Therefore, the vagueness at the level of the provisions of the constitution, it is only through the 1945 Constitution, the position and authority of the vice president can be emphasized. The issue of further amendment to the 1945 Constitution was rolled.

The constitution (written) ${ }^{37}$, as a man's work is made within a certain time, enacted, and enforced through political decisionmaking process in the political forum, will

\footnotetext{
37 The term "constitution" in this case is used to provide an overview for the set of laws that govern the state concerned and that have been compiled into a written document. The terms or concepts excluded for the United Kingdom, New Zealand, and Israel. See K.C. Wheare. (2005). Op.Cit., page. 19
}

never be perfect. ${ }^{38}$ Not perfect in this regard not only in terms of incomplete, but also in the sense that the constitution (written) in constant need of legitimacy of its time. Given that the concept of the constitution itself is dynamic, ${ }^{39}$ then the constitution amendment is a necessity..$^{40}$ According to Romano Prodi, the constitution cannot be changed is a weak constitution. It is to be weak, because the constitution cannot adapt to reality. In fact, a constitution must be adapted to the reality that is constantly changing. ${ }^{41}$ Hence also, every constitutional system should have one inherent to the ever-changing nature. Thus, a constitution cannot be changed no more than just persiflage document. It is nothing more than a false document in full pretense. ${ }^{42}$

How about the 1945 Constitution? The 1945 Constitution is man-made so that it will never be perfect. ${ }^{43}$ Therefore, the 1945 Constitution should not be immune to the change. Referring to the opinion of McWinney, the 1945 Constitution is a modern constitution that is good, because it regulates the conditions for change. In the 1945 Constitution, Chapter XVI entitled "Constitution Amendment", there is Article 37 which regulates

38 Jimly Asshiddiqie (2007). Pokok-pokok Hukum Tata Negara Indonesia Pasca Reformasi. Jakarta: PT Bhuana Ilmu Populer, page. 604

39 Francois Venter, "Constitution Making and the Legitimacy of the Constitution" in Antero Jyranki (ed) (1999), National Constitutions in the Era of Integration, page. 19

40 John P. Wheeler Jr., 'Changing the Fundamental Law' in Joh. P. Wheeler, Jr. (ed.), (1961), Salient Issues of Constitutional Revisions, , page. 49

41 Anthony Browne, 'Prodi Fears Sceptic will Neuter EU Constitution Vote 2004', http//www.vote2004.com/mediacenter/display.asp?!IDNO $=1395$. Accessed on 25 July 2011

42 Denny Indrayana (2007). Amandemen UUD 1945: Antara Mitos atau Pembongkaran. Bandung: Mizan, page. 73

43 Muhammad Ridwan Indra (1990). The 1945 Constitution: A Human Creation, page. 45 
how "formal amendment" is performed, which includes prerequisites and procedures to change the 1945 Constitution. However, the issue is not with the existence of rules on changes in the 1945 Constitution, but rather on the possibility based on an actual reality for the revision or amendment, mainly to regulate strictly the authority of the vice president. The concept of "amendment" in this article refers to the opinion of Wheeler, as a change of limited scope includes one or a limited number of rules in the constitution. ${ }^{44}$

To view the possibility of arrangements explicitly regarding the authority of the vice president through an amendment of the 1945 Constitution, there are 2 (two) important things. First, whether the arrangement is explicitly regarding the authority of the vice-president in the 1945 Constitution is new resultante that can be agreed? Second, the issue of arrangements possibility is linked with key aspects of the constitutional amendments directly confronted with the actual reality. Including analysis of the juridical-constitutional implications, especially against the presidential system adopted.

\section{Is there New Resultante?}

In the book titled "The Modern Constitutions," K.C. Wheare said that the constitution is resultante or agreement of their establisher according to the situation and conditions of political, economic, social, and cultural at the time established. According

\footnotetext{
44 John P. Wheeler Jr, "Changing the Fundamental Law", in John. P. Wheeler Jr. (ed), (1961). Salient Issues of Constitutional Revision, Wheeler distinguishes amendment with revision. According to Wheeler, revision is meant as reconsideration for all or mostly of the constitution.
}

to Moh. Mahfud MD, ${ }^{45}$ attempts to amendment the 1945 Constitution should not necessarily mean that the existing constitution is wrong or bad. The point of the attempt to make amendments to the constitution is to create a new resultante. New resultante new may arise because: (1) new developments. Included in these reasons are (i) changes in political, economic, social, and culture in the community, and (ii) the implementation of the constitution created new problems.

In that sense, the issue in question had not expected, but problems concerning the substance of the constitution which can be corrected through constitutional amendments, and (2) because there is a problem or important things passed, or it may be because it was found drawback in the constitution that are applicable while to fill gaps can only be reached by setting it in the constitution. The problem in question can stand alone as well as a series of provisions of the constitution are applicable.

Following the logic used by Mahfud $\mathrm{MD}$, the issue of amendment the constitution becomes simple, namely is there is a new resultante? If it is considered as a new resultante, then just take the deal alone. That is, when the constitution needs to be changed because there is a new situation and needs, and then only need to be agreed only. Therefore, it is possible constitution judged to be true and it was agreed at a specific time in the development assessed one at different times. Moreover, the political constellation at the period of amendment the 1945 Constitution has been very different from the

45 Moh. Mahfud MD. "Dalil Wheare tentang Konstitusi", Koran Seputar Indonesia, Dec 20, 2014 edition. 
constellation at this time. If the situation, demands and needs of the community change, then the constitution as the resultante can also be changed. If necessary, a new agreement can be taken, but if not, do not impose will unilaterally. ${ }^{46}$

On the basis of the constitutional postulates as resultante, then how about the idea of the vice-president authority arrangement in the 1945 Constitution? There are 2 (two) logic that both have justification for each proposition; (a) there is a new resultante and (b) there is no new resultante.

\section{There is new resultante}

Based on the reality of the practice during this, the absence of further regulation authority of the vice-president in the 1945 Constitution as the vice president without role other than "spare tire" for the president is the main argument of justification in this logic.

The idea of the necessity of authority arrangement in the 1945 Constitution has justification to view reality both normative and empirical that (1) the institution of presidential is a position in the organization of a system of government based on the 1945 Constitution of which consists of two positions, president and vice president, ${ }^{47}$ (2) post-amendment the 1945 Constitution, the vice president together the president are elected by the people through elections; and (3) without the explicit rules in the 1945

46 Moh. Mahfud MD. (2012). Perihal Amandemen Lanjutan UUD 1945, A paper presented on the General Lecture in order Dies Natalis ke-60 Universitas Sumatera Utara (USU), Saturday, 1 September 2012 at Universitas Sumatera Utara, Medan.

47 Jimly Asshiddiqie. (2006). Konstitusi dan Konstitusionalisme Indonesia. Jakarta: Konstitusi Press, page. 204
Constitution, "tension" between the president and the vice president will always coloring the constitutional history.

In connection with the third, the history noted, Indonesia has experienced a period of vacancy vice president for about 17 years. Precisely, since Bung Hatta resign as the vice-president on 1 December 1956. Hatta resign because he was not in line again with Sukarno on a vision of statehood. Hatta dare to bluntly criticize open to Sukarno. That is the cause of duumvirate broke up in the middle of the road. Since 1973, the position of the vice president filled by Sri Sultan HB IX as the first of vice president in the New Order.

In this era, the tension between the president and the vice president is not so perceived, because the dominant role of President Soeharto. But the tension between the president and the vice president remerge in Reform Order. Tensions between President Abdurrahman Wahid and Vice President Megawati as the culmination point of an open conflict provoked by political competition in the parliament. The strong of Jusuf Kallas' influence in parliament may contribute to frequent disputes vision between SBY and Jusuf Kalla. Its peak since Yudhoyono plans to form Unit Kerja Presiden untuk Pengelolaan Program dan Reformasi (UKP3R). Jusuf Kalla explicitly rejects the idea. The tension lasted quite a long time, until finally both have to face when they decide to compete to seize the presidency in the election in 2009.

Not only that, the practice of giving duties and authority of the president to the vice president is deemed problematic. In the 
past, President Soeharto gave the duties to his deputy only through speeches, usually after announcing a new cabinet. Even so, President Abdurrahman Wahid gave a mandate to the Vice President Megawati Soekarnoputri to deal with the problem of human rights, the environment, Irian Jaya, Aceh and Maluku, through speech after announcing the Cabinet of National Unity on 26 October 2009.

In the era of the President SBY, there is a sort of unwritten agreement about work division; the President hold the political, legal, and security fields, while Vice President Jusuf Kalla was assigned to deal with the monetary field. The problem, if it is essentially just a speech or an unwritten agreement, how the public can judge the ultimate success the vice-presidents' duties and authority given to him. How the public ask accountability, such, legally, if the Vice President has failed or negligent in performing their duties and the authority? Most likely, only done with the critique of the vice president without being able to ask for accountability.

In addition to these reasons, the arrangement of the vice president authority in the 1945 Constitution through an amendment is likely to see the background of the presence of the vice president positions. In the history of the last order, the mention of the vice president as auxiliary of the vice president is more due directly appointed by the president. Assuming, without the need to "sweat", someone can just suddenly appointed as vice-president. It is different from the practice in the reform era under the 1945 Constitution. Since the president and vice president are elected directly by the people, the vice president has a role and important contribution to the presidents' election. For example, without supported or paired with the Vice President of Jusuf Kalla, not sure President Jokowi is winning. That is, Jusuf Kalla also "sweats" in winning Jokowi. However, it appears that the context of the vice president as an "auxiliary" the president is very different between the past and the present, the conditions and the dynamics are different.

The description above is impressive just how urgent the authority of the vice president in the 1945 Constitution so that the boundaries of authority and the employment relationship is obvious. Concrete problems that exist with respect to the work relation of the president and vice-president due to unclear authority in the Constitution 1945 it can be said to have met the prerequisites as new resultante. Tensions that characterize relations between the president and vice president can only be said to occur as the implications of the absence of further rules regarding the authority of the vice president in the 1945 Constitution. Therefore, the problem can only be solved through regulation in the constitution. Therefore, the new resultante makes the amendment of the 1945 Constitution as necessary thing to do, in this case to assert and specify the boundaries of the authority of the vice president.

\section{No new resultante}

The logic of "no new resultante" comes from the argument of the founding fathers that held the position of vice-president to the passive position and prepared to fill the void of presidential, either temporary or 
permanent, as stated in Article 8 (1) the 1945 Constitution. According to the logic, the role and duties of the vice president as stipulated in the 1945 Constitution is very clear, so they no longer need to be made specific. Article 4 (2) of the 1945 Constitution states, "In implementing his/her obligations, the President shall be assisted by one Vice President". The problem, what is meant by the word "assisted"? Moreover, Article 17 paragraph (1) of the 1945 Constitution is stated, the President assisted by ministers. So, what is the difference the quality of assistance by the vice-president than with the assistance of ministers?

According to Article 4 (2) of the 1945 Constitution, the vice president is president auxiliary in performing his duties. As discussed earlier, the vice president has the possible positions of the president, such as (i) as a vice representing the president, (ii) as substitute the president; (iii) as auxiliary the president; (iv) as counterpart the president. The position the vice president cannot be separated by the president as a single position that elected directly by the people through elections. President and vice president is an institution. Anyway, the process to become the vice president as president through elections, in contrast to the designated minister. Therefore, the position of vice president is higher and more important than ministers. ${ }^{48}$

Therefore, how the vice president assist the president to perform presidents' duties and carry out the assignment of the president is not appropriate if there are ministers who

48 Jimly Asshiddiqie (2009). Komentar Atas Undang-Undang Dasar Negara Republik Indonesia Tahun 1945. Jakarta: Sinar Grafika, pages.21-22 are not performing orders of the president and vice president. In this case also, the president has the authority to determine, the type of "assistance" what is to be given the vice president and asked of ministers. Even if there are problems in it, the president is also authorized to resolve. Such the real ideology of the state administration and the presidential system design according to the 1945 Constitution.

Based on the description above, the author firmly independently that there is no new resultante related to the position and authority of the vice president. Consequently, it is not necessary the amendment of the 1945 Constitution, it is intended to clarify the duties, functions and position of vicepresident. In fact, according to the author, there will be some problems if the vice president was given the authority in detail in the 1945 Constitution. The intended issues are described into 5 (five) things, as follow:

First, the arrangement of the vice presidents' authority in detail in the Constitution 1945 can be regarded as an opportunity "to undermine" the president who from the beginning designed to have a strong authority as the sole leader in the presidential government system.

Second, detailed arrangement of the vice presidents' authority will have difficulties. At the time of the Constitution 1945 stipulates the boundaries of the vice presidents' authority, the president is very likely difficulty or cannot even get into the authority of the vice president. This creates an anomaly amid strengthen the spirit of presidential government system. The arrangement in the Constitution 1945 as applicable now it was 
appropriate, because the president as chief of executive at any time can take away the authority of the vice president and ministers.

Third, with a clear and detailed authority in the Constitution 1945, the position of the vice president is no longer a mere "auxiliary" or "counterpart", it is likely to move into a "competitor" of the president. In fact, in the presidential government system, the vice-president must be a figure in line with the president, is willing to step behind the president, and not be able to "shine" of the president.

Fourth, with explicit authority in the 1945 , it may open a space for a vice president to be different or even disagree with the president. Moreover, in the history and reality in various countries, including in Indonesia, distrust always inherent to the relationship between the president and the vice president.

Fifth, the vice president can be referred to individually ${ }^{49}$ as a state organ whose existence and authority mentioned in the Constitution 1945. By authorizations mentioned clearly and in detail in the Constitution 1945, the vice president can be subjectum litis in the case of Sengketa Kewenangan Lembaga Negara (SKLN) in the Constitutional Court. When the vice president felt his/her constitutional authority inhibited or prevented in casu by the president, the vice president can submit SKLN to the Constitutional Court. Although, this is highly predictive, but likely to occur at anytime. If this occurs, there is no other word the design of presidential government system based on the Constitution 1945 is broken.

49 See, Ni'matul Huda. (2007). Lembaga Negara dalam Masa Transisi, Yogyakart: UII Press, pages. 90-91.
Assessing the Possibility of the 1945 Constitution Amendment

However, a large flow of public aspirations in favor of the login in new resultante, that the development of the actual situation necessitates the arrangement of the vicepresidents' authority in the Constitution 1945, the biggest challenge this notion is on how its possibility to make it as a new agreement, as stated by Mahfud MD? Said to be a big challenge, as seen from the facts, the proposed to re-amendments in the 1945 Constitution always foundered.

For example, as once intended by the Regional Representative Council. ${ }^{50}$ Although, it cannot be denied, beyond the matter of detailed arrangement of the Vice Presidents' authority, in fact according to the author, there are a number of new resultante, mainly as a consequence of the weaknesses of the 1945 Constitution, both of which appeared since the beginning of the amendment is set and became known only after the 1945 Constitution as results of the amendment over than a decade. ${ }^{51}$

50 An effort of the Regional Representatives Council (DPD) proposed the 1945 Constitution amendments have been made since mid-June 2006. At that time, some of the member of the Regional Representative Council is formally propose changes to the Chairman of MPR. DPD intends to strengthen its capacity in legislation, particularly related to Article 22D the 1945 Constitution because it only concerns the authority of DPR, a majority of the Parliament requested that DPD prepare a more comprehensive proposed changes. After successfully drafting a comprehensive change, DPD also conduct intensive communication with the political forces in the Parliament. The support of several members of the House of Representatives (DPR) was coming with signature as a sign of support of the Parliament's suggestions. However, in the end, some supporters withdrew its support, for any reason, it is not time to amend the 1945 Constitution. The amendment proposed of the 1945 Constitution again supported by DPR 2009-2014. But again, the proposal is foundered; it is regarded favor DPD, the proposal is getting trouble from political forces that exist.

51 The 1945 Constitution as results of amendment are 
Theoretically, there are 3 (three) key aspect of the constitutional amendments, ie (1) when the amendment can be done; (2) how the amendments made; and (3) how public participation in the amendment. Analysis of the actual reality that is faced with three key aspects of the above would be to provide answers and a description of the possibility in question.

In this matter, when the constitution was amended, Robert Goldwin and Art Kaufman said, a constitutional amendment is only possible on the tremendous momentum in the history of a nation. ${ }^{52}$ The question is tremendous momentum as what is meant Goldwin and Kaufman? According to Von Savigny, momentum can be outside it is momentum that happens when a nation has fully achieved political maturity and its laws. ${ }^{53}$ In contrast to the opinion of Savigny, John Elster called the 8 (eight) conditions that allow the constitutional amendments, ie (i) the social and economic crisis, (ii) the revolution, (iii) the collapse of a regime, (iv) the fear of the collapse of a regime, (v) defeat in the war, (vi) post-war reconstruction; (vii) the establishment of a new country; and (viii)

considered still leaves problems and drawback. In addition to the construction of articles (legal drafting) is elusive, many substance changes not in line with efforts to construct checks and balances. In a legislative function, there is authority that is not balanced between the Parliament and the Parliament. The construction of Article 22D makes DPD just a mere accessory legislation. Similarly, the character of parliamentary is still present, among other things with still given the right of inquiry and interpellation. Then, regarding the closing of the place for the presidential candidate of the individual lines is considered as a fundamental weakness in the process of executive positions.

52 Robert A. Goldwin and Art Kaufman (ed). (1988). Constitution Makers and Constitutio Making: The Experience of Eight Nations, page. 1

53 Von Savigny as cited in Denny Indrayana. (2007). Amandemen UUD 1945: Antara Mitos atau Pembongkaran, Bandung: Mizan, page. 79 independence from colonial rule. ${ }^{54}$

In other languages, Bogdanor mention the need of political turmoil to amend the constitution. The political turmoil, according to Bogdanor, comes as pressure is demanding changes to the constitution as the constitution of a country is no longer congruentline with the values of social and political trends are changing. ${ }^{55}$ More specifically, Wheare mention, decent least amended constitution does not only depend on the laws governing the amendment method, but also depends on the configuration of political and social groups that exist. That is, as long as the groups are satisfied with the performance of the existing constitution, the constitutional amendment would not be possible. As similar in the view of Bogdanor, Wheare said, in a turbulent political situation, the political configuration typically changes dramatically, then the chances of amending the constitution to be larger. ${ }^{56}$

As to how the constitutional amendment is done, there is a idiom that the facts in the process of constitutional amendment affecting the substance of the constitution. ${ }^{57}$ Bonime-Blanc categorizes this process into 3 (three) types, ie (a) consensual, (b) disensual, and (c) stillborn. Consensual is the best type, because the constitutional amendment process that is consensual has 4 (four) characteristics, namely (i) requires the participation of all parties, or at least most of the political groups that exist, (i) an agreement was reached to ensure the accountability and

\footnotetext{
54 John Elster. (1995). "Force and Mechanism in the Constitution Making Process", Duke Law Journal, 45: 347. 55 Bogdanor as cited in Denny Indrayana, Op.Cit, page. 80 56 K.C. Wheare, Konstitusi-Konstitusi ..., Op.Cit, page. 23 57 Bonime-Blanc as cited in Denny Indrayana, Op.Cit, page. 80
} 
utilizing a compromise, (iii) compromise often causing confusion, and (iv) although there is confusion, but there is no group that really does not agree with the draft amendments to the constitution. Because basically, most continue to provide support to the draft amendment is generated.

The agreement is relatively difficult to achieve. Even, if achieved, often involving objections to the opinions proffered by the main political groups. Consequently, the potential threat to the political system is wide open, especially on the line hurt. While in the stillborn process, the constitutional amendment failed before enacted. An institution that has the authority to amend the constitution is not capable to generate a draft constitutional amendment. The failure occurs due to the differences arising is too deep, making it difficult to achieve the dominant coalition. Its main characteristics, the constitution failed to be created, or, if established, is not approved nationally.

Meanwhile, related to the public participation, Wheare, ${ }^{58}$ said that public participation is crucial in amending the constitution. Public participation is necessary to ensure that a constitutional amendment is not a mere political elite product. In addition, public participation in the view of Ihonvbere, ${ }^{59}$ helping a sense of people ownership on the results of the constitutional amendment. Therefore, the constitution will be the property of the people, who will always be defended and preserved. Moreover, if the constitutional amendment is considered as

$58 \quad$ K.C. Wheare, Op.Cit, page. 122

59 Julius Ihonvbere. (2000). 'How to Make an Undemocratic Constitutional: The Nigerian Example', 21:2 Third World Quarterly, page. 346 extensive efforts to solve social problems and politics, ${ }^{60}$ making a constitutional amendment is in favor of the political elite and ignores the role of public participation. Bonime-Blanc suggested, because the constitution is not only dealing with the government rule, but in the end also touched the rights and obligations of the people, public participation should be given more in the constitutional amendment. ${ }^{61}$

Using the three key aspects as described above, how the possibility of the 1945 Constitution amendment, particularly associated with the will to regulate in detail the authority of the vice-president?

First, when referring to the 8 (eight) conditions as Elsters' view, the actual reality shows none of these conditions are met. Although characterize the problems in various fields, but according to the author, there is tremendous momentum that supports argumentation the constitutional amendment. The issue that hit, generally a further implications of the democratic euphoria of the post-reform. In this case, the author expressly states that there has not been sufficient argument to say that the problems that occur today due to the weakness of the 1945 Constitution amendment.

The condition of "expansion of the authority of the Chief of Presidential Staff" and "Rizal Ramli vs Kalla" not yet qualify as tremendous momentum. These events just "noise" political then suddenly withdrawn as a problem on the obscurity of the 1945 Constitution regulate the authority of the vice president. Epicenter not placed in the

$60 \quad$ Denny Indrayana, Op.Cit, page. 74

$61 \quad$ Ibid 
obscurity norm in 1945 Constitution in casu Article 4 paragraph (2) of the 1945 Constitution, but rather on a common reality that occurs in many countries that scans a written constitution into constitutional practice is not an easy matter.

Second, as stated by Wheare, a constitutional amendment is affected by the configuration of political and social groups that exist. In reality, even if there is a group that wants a constitutional amendment, the amount is not equivalent to the group is satisfied with the 1945 Constitution today. Moreover, the absence of "tremendous momentum" make the idea of the 1945 Constitution amendment is less response. According Saldi Isra, ${ }^{62}$ the lack of support for the idea to amend the 1945 Constitution is not due to the lack of gold momentum, but rather the fear of loss of enjoyment gained from the 1945 Constitution amendment. Hard to argue, one of the most state institutions enjoys the design of the 1945 Constitution amendment is the House of Representative.

According to the author, the idea of advanced amendments which aims to close "holes" of the 1945 Constitution amendment ${ }^{63}$ since the beginning recognized by the People Consultative Assembly ${ }^{64}$ have been less addressed by political forces that exist, especially on the issue of the details of the

62 Saldi Isra, "Memastikan Amandemen Kelima". Koran Tempo, 1 August 2011

63 See footnote no. 53

64 The recognition of the drawback the 1945 Constitution amendment is marked by the presence of TAP MPR No. I / MPR / 2002 on the establishment of the Constitutional Commission (CC). In Article 1 of TAP MPR, MPR assigns $\mathrm{CC}$ to conduct comprehensive assessment on the results of the 1945 Constitution amendment. After the assessment, $\mathrm{CC}$ recommends a number of improvements. But after submitted to the MPR, these results until now are not necessarily trace. vice presidents' authority, in the past it is never questioned. Thus, to see the configuration of political forces today, especially in the People Consultative Assembly (MPR), the opportunity to amend the 1945 Constitution, especially include an idea to clarify the authority of the vice president is no bigger than a pinhole.

Third, there is the impression is quite obvious that the detailed arrangements of the vice presidents' authority through the 1945 Constitution amendment is "a moment opname" on "the expansion of the authority of Chief of Presidential Staff' and 'Rizal Ramli vs Kalla'. As a result, in the eyes of the public, a constitutional amendment just " $a$ chunk" the interests of the political elite that did not touch the public interest. Needed a tremendous struggle for its initiators to build the best possible opinion for justification that the arrangement of the vice presidents' authority in the 1945 Constitution is rated by the people as new resultante.

On paper, this is difficult, because the substance of the detailed arrangements of the vice presidents' authority is clearly based on the elite for the elite only. In fact, that idea of amendment was well received by the peoples; the issue should be linked to the fulfill demands and interests of the people that cannot be met by the 1945 Constitution that now prevails. In the past, when formulating the 1945 Constitution, Yamin reminded the need for firmness thought that the constitution is being formulated welcomed by the people. For that, Yamin ${ }^{65}$ stated, "We want to guarantee in our constitution the correction

\footnotetext{
65 Muhammad Yamin, (1959). Naskah Persiapan Undang-Undang Dasar 1945. First edition. Jakarta: Prapantja, page. 239
} 
for all Indonesian people. Therefore, in the basic law is explained in one article, which related to the welfare, spritual, material and economic welfare."

In other words, it is unclear the symptoms that idea to regulate in detail the authority of the vice-president in 1945 Constitution as the aspiration of the people, let additionally refer to it as the needs of the Indonesian people. Although, according to Peter Paczolay, in the case of minor amendments and not the new constitution, approved by regulatory authorities to amend change the constitution would be enough, ${ }^{66}$ but Thomas Paine said, a constitution is not the act of a government alone, but an act of the people who make up the government. ${ }^{67}$ Therefore, without the popular participation of people, is difficult to expect the results of the 1945 Constitution amendment. Then, difficult to expect people moved to defend and sustain the results of the 1945 Constitution amendment.

\section{CONCLUSION}

Based on the analysis and discussion above, the author believes that, (i) although it is not mandatory referral, the constitutions of other countries do not specify the authority of the vice president and put the vice-president as a "spare tire" when the president is absent; (ii) there is no new resultante about the position and authority of the vice president so that theoretically is not reason enough to regulate

66 Peter Paczolay (1993). "Constitutional Transition and Legal Continuity”, Connecticut Journal of International Law, page. 568

67 Thomas Paine, Rights of Man, Constitution Society (1787), Available online at; http://www.constitution. org/tp/rightsman2.htm. Accessed on 23 April 2010 at 17.09 WIB in detail the authority of the vice president through an amendment of the 1945 Constitution; (iii) detailed arrangements in the authority of the vice-president in the 1945 Constitution holds the potential to chaos the presidential system design is based on the 1945 Constitution; and (iv) therefore, the possibility of the vice-presidents' authority arrangement in the 1945 Constitution was very small, both in terms of momentum and the substance of the issues.

The author is more agree if the arrangement of work relationship between the president and the vice president is set, but not at the level of the 1945 Constitution. Its arrangement should not be to specify the authority of the vice president, but arrange clearly how the mechanism and the type of "assistance" given to the vice president. The most important thing should also be stated in the legal system is arrangement for the vice president took no action beyond the authority and exceed his position as the 1945 Constitution.

\section{BIBLIOGRAPHY}

Anthony Browne. "Prodi Fears Sceptic will Neuter EU Constitution Vote 2004", Source: http//www.vote2004.com/mediacenter/display.asp?!IDNO=1395. Accessed on 25 July 2011.

Arthur Schlesinger Jr. "Is the Vice Presidency Necessary?" Available online at: http://www.theatlantic.com/magazine/ archive/1974/05/is-the-vice-presidency-necessary/305732/. Accessed on 11 November 2015.

Bagir Manan and Kuntana Magnar. (1997). Beberapa Masalah Hukum Tata Nega- 
ra Indonesia. Bandung: Alumni.

Colombia's Constitution of 1991 with Amendments through 2005. Available online at: https://www.constituteproject.org/constitution/Colombia_2005. pdf. Accessed on Thursday, 12 November 2015 at $09.30 \mathrm{WIB}$

Denny Indrayana. (2007). Amandemen UUD 1945: Antara Mitos atau Pembongkaran. Bandung: Mizan.

Detik News. "Memperjelas Tugas Wapres, Ketua DPD: Perlu Amandemen UUD 1945 untuk Perkuat Peran Wapres”. Available online at: http://news.detik. com/berita/2999506/ketua-dpd-perluamandemen-uud-1945-untuk-perkuatperan-wapres. Accessed on 24 August 2015.

Harun Al Rasyid. (1999). Pengisian Jabatan Presiden. Jakarta: Pustaka Utama Graffiti.

James E. Hoare. (2015). Historical Dictionary of the Republic of Korea. $3^{\text {rd }}$ Edition. Maryland: Rowman \& Littlefield.

Jimly Asshiddiqie. (2006). Konstitusi dan Konstitusionalisme Indonesia. Jakarta: Konstitusi Press.

(2007). Pokok-pokok Hukum Tata Negara Indonesia Pasca Reformasi. Jakarta: PT Bhuana Ilmu Populer. . (2009). Komentar Atas Undang-Undang Dasar Negara Republik Indonesia Tahun 1945. Jakarta: Sinar Grafika.

John Elster. (1995). "Force and Mechanism in the Constitution Making Process", Duke Law Journal, 45: 347.
Juergen Kleiner. (2001). Korea A Century of Change, Economic Ideas Leading to the 21st Century. Vol. 6, World Scientific Publishing Co. Pte. Ltd.

Julius Ihonvbere. (2000). 'How to Make an Undemocratic Constitutional: The Nigerian Example', Third World Quarterly, 21:2.

K.C Wheare. (1966). Modern Constitution. $2^{\text {nd }}$ Edition. Oxford Paperbacks University Series: Oxford University Press. . (2005). Konstitusi-konstitusi Modern. Surabaya: Eureka.

Kompas. "JK Mengaku Tidak Diajak Komunikasi Saat Jokowi Bentuk Perpres untuk Luhut". March 4, 2015 edition.

Moh. Mahfud MD. (2012). Perihal Amandemen Lanjutan UUD 1945, A paper presented on the General Lecture in order Dies Natalis ke-60 Universitas Sumatera Utara (USU), Saturday, 1 September 2012 at Universitas Sumatera Utara, Medan.

$$
\text { "Dalil Wheare tentang }
$$
Konstitusi”, Koran Seputar Indonesia, Dec 20, 2014 edition.

Muhammad Yamin, (1959). Naskah Persiapan Undang-Undang Dasar 1945. $1^{\text {st }}$ edition. Jakarta: Prapantja.

Musmuliadin. (2013). "Tugas dan Kewenangan Wakil Presiden dalam Sistem Presidensiil Berdasarkan Undang-Undang Dasar Negara Republik Indonesia Tahun 1945", Jurnal Ilmiah, Fakultas Hukum Universitas Mataram.

Ni'matul Huda. (2007). Lembaga Negara dalam Masa Transisi. Yogyakarta: 
UII Press.

Peter Paczolay (1993). "Constitutional Transition and Legal Continuity", Connecticut Journal of International Law, 568.

Robert A. Goldwin and Art Kaufman (ed). (1988). Constitution Makers and Constitutio Making: The Experience of Eight Nations.

Robert Valencia. (2012). "Are Vice Presidents Necessary?". Available online at: http://www.worldpolicy.org/ blog/2012/09/06/are-vice-presidentsnecessary. Accessed on 11 November 2015 at 18.17 WIB.

Roy B.B. Janis. (2008). Wapres: Pendamping atau Pesaing? Peranan Wakil Presiden dalam Sistem Ketatanegaraan Republik Indonesia, Jakarta: Bhuana Ilmu Populer.

Saldi Isra, "Memastikan Amandemen Kelima”. Koran Tempo, 1 August 2011.

Soong Hoom Kil and Chung-in Moon (ed.).
(2001). Understanding Korean Politics: An Introduction. New York: State University of New York Press.

Sri Soemantri. (1993). Tentang Lembagalembaga Negara Menurut UUD 1945. Bandung: Citra Aditya Bakti.

Tempo News. "Ditantang Debat Terbuka, Wapres JK Akan Panggil Rizal Ramli”, available online at: http:// nasional.tempo.co/read/news/ 2015/08/19/078693268/ditantang-debat-terbuka-wapres-jk-akan-panggilrizal-ramli. Accessed on 15 May 2015.

This Nation. "Why did the Founding Fathers create the Vice Presidency?" http:// www.thisnation.com/question/039. html. Accessed on 11 November 2015 at 18.05 .

Thomas Paine, Rights of Man, Constitution Society (1787), http://www.constitution.org/tp/rightsman2.htm. Accessed on 23 April 2010. 